\title{
PENERAPAN ACADEMIC VOICE DENGANG MENGGUNAKAN APA (AMERICAN PSYCHOLOGICAL ASSOCIATION) STYLE DALAM PENULISAN KARYA TULIS ILMIAH BAGI GURU MA AN-NAMIRAH TANAH MERAH BANGKALAN
}

\author{
Moh. Hafidz ${ }^{1}$, Hendra Sudarso ${ }^{2}$ \\ STKIP PGRI Bangkalan

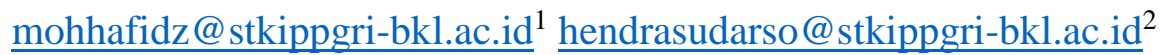

\begin{abstract}
Training participants' understanding of academic voice and skills using APA (American Psychological Association) Style are out of academically standard. The purpose of this community service is to convey knowledge of academic voice and practice the skills of using APA Style in scientific writing. The benefit of this community service is making trainees easy for writing quotation and references automatically and avoid plagiarism.

The method used observation to find out the problem of participants in scientific writing, identification to specify the scope of community service deal with the needs of participants related to scientific writing and mobilization to provide solutions both in discussing material and applying APP Style. The result of this community service are the trainees are able to master academic voice and citation techniques and be able to implement the APA (American Psychological Association) Style in writing citations and references automatically.

Key Words: Academic Voice, APA Style, Academic Writing
\end{abstract}

\section{ABSTRAK}

Pemahaman peserta pelatihan terhadap academic voice dan keterampilan menggunggunakan APA (American Psychological Association) Style masih sangat lemah. Tujuan pengabdian ini adalah untuk menyampaikan pengetahuan tentang academic voice dan melatih keterampilan menggunakan APA Style dalam penulisan karya tulis ilmiah. Manfaat pengabdian ini adalah memudahkan peserta pelatihan dalam penulisan pengutipan dan refrensi secara otomatis dan terhindar dari plagiasi.

Metode yang digunakan dalam pengabdian ini adalah observasi untuk mengetahui masalah peserta dalam penulisan karya tulis ilmiah, identifikasi untuk mempersempit lingkup pengabdian sesuai dengan kebutuhan peserta berkaitan dengan karya tulis ilmiah dan mobilisasi untuk memberikan solusi terhadap permasalahan baik berupa penyampaian materi maupun penerapan aplikasi. Hasil pengabdian ini adalah peserta pelatihan mampu menguasai academic voice dan teknik pengutipan dan mampu menerapkan APA (American Psychological Association) Style dalam penulisan pengutipan dan referensi secara otomatis.

Kata Kunci: Academic Voice, APA Style, Karya Tulis Ilmiah

\section{PENDAHULUAN}

Artikel ilmiah adalah salah satu cara untuk menyebarluaskan ilmu pengetahun bahkan sebagai syarat untuk kenaikan pangkat bagi guru-guru khususnya ditingkat Sekolah Lanjutan Tingkat Atas (SLTA) yang tertuang dalam Peraturan Menteri PAN \& RB No 16 tahun 2009 tentang Jabatan Fungsional Guru. Dalam mempublikasikan jurnal, penulis dituntut untuk menulis sesuai dengan kaidah penulisan karya ilmiah. 
Penulis mempunyai cara masing-masing untuk mengungkapkan suara atau ragam gramatikal (Academic Voices) meskipun mengalami kesulitan karena hal ini sangat personal dan tergantung pada waktu dan tujuan penulis (Christian F, 2017). Cara yang digunakan penulis untuk menyampaikan gagasan sendiri maupun gagasan orang lain masih belum sesuai dengan standar pengetahuan academic voices (Melbourne University, 2012).

Academic Voices (ragam gramatikal) adalah bentuk pernyataan yang diungkapkan melalui tulisan dengan menggunakan kiasan dari sumber pribadi maupun sumber lain (Davina B, 2015). Definisi ini digunakan untuk kaidah ragam gramatikal oleh penulis dalam menulis artikel ilmiyah, karena banyak penulis artikel hanya menggunakan menekankan pada bahasa penulis (writer's voice) dalam mengungkapkan gagasannya (Hafidz, 2018) seperti halnya yang dilakukan oleh beberapa guru di MA- An-Namirah Tanah Merah Kabupaten Bangkalan.

Selain hal tersebut, guru-guru masih lemah dalam hal pengutipan, khusunya dalam menggunakan format APA style dalam penulisan karya tulis ilmiah, karena banyak guru belum mengetahui bahwa format tersebut digunakan dalam berbagai disiplin keilmuan untuk menulis referensi secara otomatis (Tim Dosen Jurusan Ilmu Komunikasi FISIP-UB, 2013). Sehingga permasalahan yang muncul adalah tingginya tingkat plagiasi dalam penulisan artikel jurnal, lemahnya guru-guru dalam pemahaman dan penerapan Academic Voice dan lemahnya guruguru penulisan referensi secara otomatis dengan menggunakan APA Style.

Dari hasil analisa diatas, maka penulis melakukan pelatihan Penerapan Academic Voice dengang menggunakan APA (American Psychological Association) Style dalam penulisan karya tulis ilmiah bagi guru Ma An-Namirah Tanah Merah Bangkalan.

\section{METODE PELAKSANAAN}

Metode pendekatan yang digunakan dalam pengabdian ini adalah Observasi, pengabdian ini dilakukan dengan tahapan observasi terlebih dahulu untuk mendapatkan informasi dan data secara lengkap dan valid dari guru yang sudah pernah menulis artikel ilmiah tentang penggunaan pengutipan dan 
penulisan referensi secara otomatis. Identifikasi, Setelah informasi dan data terkumpul, tim melakukan pemetaan terhadap permasalahan berkaitan dengan pengutipan dan penulisan referensi secara otomatis. Mobilisasi, ari permasalahan yang ada, tim berkoordinasi untuk mengelompokkan peserta pelatihan sesuai dengan kondisi masalah masing-masing peserta untuk diberikan pendampingan sealam proses pelatihan.

Terakhir Pelaksanaan, pelatihan ini dilaksanakan selama 3 (tiga). Hari pertama, pemateri pertama menjelaskan dan mendiskusikan tentang Academic voice. Setelah itu, peserta dikelompokkan sesuai dengan kelompok yang sudah ditentukan beserta pendampingnya untuk melakukan pengutipan berdasarkan Academic voice. Kemudian di hari kedua, pemateri menjelaskan tentang cara menggunakan penulisan referensi secara otomatis dengan menggunakan APA Style. setelah itu, peserta dikelompokkan kembali sesuai dengan kelompok yang sudah ditentukan beserta pendampingnya untuk menerapkan APA Style.

Pada hari ketiga, peserta dievaluasi untuk melakukan pengutipan berdasarkakan Academic voice dengan menggunakan format APA Style. Hasil dari evaluasi ini, tim akan mendapatkan kesimpulan tentang penerapan Academic Voice dengang menggunakan APA (American Psychological Association) Style dalam penulisan karya tulis ilmiah.

\section{HASIL DAN PEMBAHASAN}

Peserta pelatihan terdiri dari 13 guru mata pelajaran, terdapat $30 \%$ peserta sudah tersertifikasi dan $90 \%$ peserta telah melakukan amanah undang-undang yang tertuang Peraturan Menteri PAN \& RB No 16 tahun 2009 tentang Jabatan Fungsional Guru, yaitu telah membuat laporan penelitian berupa karya tulis ilmiah dan belum terpublikasi. Dari masing-masing peserta, diambil 5 sampel untuk dilakukan cek plagiasi hasilanya adalah dibawah 20\% tingkat kesamaannya, yang paling tinggi adalah $15 \%$ dan yang paling rendah adalah $7 \%$. Dari data tersebut, tingkat kesamaan penulisan terjadi didalam pengutipan. Pengutipan yang digunakan oleh peserta pelatihan sangat sederhana yaitu dengan menggunakan pengutipan tidak langsung yang penulisnya ditaruh di akhir kalimat (external voice) (Hafidz, 2018). 
Karya tulis peserta banyak yang menggunakan rujukan berupa buku-buku, jarang sekali menggunakan artikel ilmiah hasil penelitian yang terpublikasi karena lemah dalam mengakses pengetahuan baru yang berkaitan dengan materi ajar. Pengutipan tersebut masih sangat monoton dan masih membutuhkan penguatanpenguatan untuk menulis karya tulis yang ideal (Melbourne University, 2012) baik secara isi, teknik penulisan maupun sistematika penulisan karya tulis. Salah satu penguatannnya adalah mengikuti pelatihan penulisan karya tulis ilmiah.

Dalam pelatihan ini, peserta dikenalkan dengan beberapa cara tentang pengutipan seperti gagasan penulis (writer's voice), gagasan orang lain secara langsung (direct voice), secara tidak langsung (indirect voice) dan secara tidak langsung tapi tambahan (external voice) (Hafidz, 2018) untuk menulis kembali sumber yang dikutip sesuai dengan bahasanya sendiri. Peserta diminta untuk mengutip satu paragraf dari salah satu buku kemudian menuliskan kembali dengan menggunakan empat cara diatas, disinilah peserta mengalami tantangan untuk menulis sesuai dengan tujuan masing-masing masing peserta (Christian F, 2017). Teknik pengutipan yang digunakan juga berbeda-beda, ada yang menggunakan dengan cara parafrase, membuat kesimpulan dan ada juga yang menggunakan dengan cara menulis poin-poinnya saja, penulisan pengutipan juga disertai dengan penulisan referensi.

Penulisan referensi bagi semua peserta pelatihan masih menggunakan penulisan secara manual, ini tidak mengacu pada standar penulisan karya tulis ilmiah (Melbourne University, 2012) yang dibutuhkan oleh penerbit jurnal baik terakreditasi maupun tidak terakreditasi. Standar penulisan rujukan yang masih banyak digunakan oleh penerbit jurnal adalah format APA (American Psychological Association) Style (Tim Dosen Jurusan Ilmu Komunikasi FISIPUB, 2013) meskipun ada beberapa jurnal yang merekomendasikan format Mendele style atau sejenisnya tetapi peserta pelatihan masih belum mempunyai aplikasinya. Sehingga penerapan penggunaan APA (American Psychological Association) Style sangat efektif bagi peserta pelatihan.

Penerapan penggunaan APA (American Psychological Association) Style selama pelatihan berlajalan dengan lancar, karena masin-masing peserta membawa laptop semua dan artikel yang masih menggunakan penulisan rujukan 
secara manual. Sehingga ketika penerapan APA Style, semua peserta sudah mempunyai bahan untuk mengutip mulai dari, nama pengarang, judul buku, tahun dan penerbit dan memudahkan peserta untuk menulis daftar pustaka secara otomatis (Tim Dosen Jurusan Ilmu Komunikasi FISIP-UB, 2013) sesuai dengan standar penulisan.

\section{KESIMPULAN}

Penulisan academic voice bagi guru membutuhkan latihan untuk menghindari kesamaan dalam penulisan gagasan sendiri dengan gagasan orang lain (plagiasi). Untuk menunjang penulisan academic voice didalam karya tulis ilmiah yang akan dipublikasi, maka APA (American Psychological Association) Style sangat dibutuhkan sebagai standar penulisan pengutipan dan refrensi. Sehingga pihak penerbit mudah untuk menerima dan mempublikasikan karya tulisnya.

\section{DAFTAR PUSTAKA}

Christian F, E. a. (2017). EFL Learners' Development Of Voice In Academic Writing: Lexical bundles, Boosters/Hedges and Stance-taking Strategies. Gist Education and Learning Research Journal, 100-101.

Davina B. (2015). Writing to be Heard: Authorial Voice in the Written Discourse of Chinese International Students. Tasmania: University of Tasmania.

Hafidz, M. (2018). Ragam Gramatikal dalam Artikel Ilmiah (Academic Voice) di E-Journal. Al-Tanzim, 185-191.

Melbourne University. (2012, October 10). Academic Skills. Retrieved October 10, 2018, from www.services.unimelb.edu.au/academicskills: https://services.unimelb.edu.au/academicskills

Tim Dosen Jurusan Ilmu Komunikasi FISIP-UB. (2013). Sistem Pengutipan / Rujukan (Referencing) APA Referencing System. Malang: Universitas Brawijaya. 